\title{
Catechin Attenuates the Effect of Combined Arsenic and Deltamethrin Toxicity by Abrogation of Oxidative Stress and Inflammation in Wistar Rats
}

\author{
Afolabi Olusegun Kayode ${ }^{1,}$, , Arinola Abimbola ${ }^{1}$, Aderibigbe Felix Adesola ${ }^{1}$, \\ Folarin Dasola Teslim ${ }^{1}$, Wusu Adedoja Dorcas ${ }^{2}$ \\ ${ }^{1}$ Department of Biochemistry, Faculty of Basic Medical Sciences, Ladoke Akintola University of Technology, Ogbomoso, Nigeria \\ ${ }^{2}$ Department of Biochemistry, Faculty of Science, Lagos State University, Ojo, Lagos
}

Email address:

okafolabi@lautech.edu.ng (A. O. Kayode)

${ }^{*}$ Corresponding author

\section{To cite this article:}

Afolabi Olusegun Kayode, Arinola Abimbola, Aderibigbe Felix Adesola, Folarin Dasola Teslim, Wusu Adedoja Dorcas. Catechin Attenuates the Effect of Combined Arsenic and Deltamethrin Toxicity by Abrogation of Oxidative Stress and Inflammation in Wistar Rats. Advances in Biochemistry. Vol. 7, No. 2, 2019, pp. 51-58. doi: 10.11648/j.ab.20190702.12

Received: July 27, 2019; Accepted: August 18, 2019; Published: August 26, 2019

\begin{abstract}
This study was aimed at evaluating the protective role of catechin (CT) against toxicity induced by combined exposure to arsenic (As) and deltamethrin (DM) in rats. Thirty-five (35) male Wistar rats were divided into 5 groups of 7 animals each. Treatment of each group was as follows: Control (C) administered corn oil $\left(1 \mathrm{ml} \mathrm{kg}^{-1}\right)$, catechin only (CT) at $40 \mathrm{mg} \mathrm{kg}^{-1}$, As+DM administered As (100ppm) in their drinking water and DM at a dose of $7.5 \mathrm{mg} \mathrm{kg}^{-1}\left(1 / 20^{\text {th }} \mathrm{LD}_{50}\right), \mathrm{As}^{+} \mathrm{DM}$ $\mathrm{CT}_{40}$ treated as As+DM in addition to oral administration of CT at $40 \mathrm{mg} \mathrm{kg}^{-1}$ while the last group, As $+\mathrm{DM}-\mathrm{CT}_{80}$ received the same treatment as As+DM, along with oral CT treatment at a dose of $80 \mathrm{mg} \mathrm{kg}^{-1}$. The treatment lasted for 28 days. Effect of the treatment in inducing oxidative damage was appraised by estimating levels of lipid peroxidation, protein oxidation, glutathione and total antioxidant capacity in the liver, kidney, and testis of the rats. Also, the activities of superoxide dismutase, catalase, and glutathione peroxidase were assayed in the tissues. For the evaluation of inflammation, plasma levels of interleukin-6, tumor necrosis factor-alpha and 8-nitroguanine were determined. The result showed that the combination of As and DM gave rise to marked alterations of these parameters but supplementation with CT attenuated these effects.
\end{abstract}

Keywords: Arsenic, Deltamethrin, Oxidative Stress, Inflammation, Catechin

\section{Introduction}

Humans are exposed to a large number of environmental contaminants. With the myriad of pollutants present in the environment, exposure to complex mixture of environmental toxic agents is the rule rather than the exception. Among these environmental agents are metals and pesticides, which are highly ubiquitous owing to their widespread use $[1,2]$. One of the most hazardous metals according to the Agency for Toxic Substances and Disease Registry is arsenic [3]. Humans are exposed to this metalloid through contaminated water, soil and through occupational exposure [4]. Exposure to arsenic (As) has been associated with a wide range of toxic effects $[5,6]$. These toxic effects include cancer of various types, diabetes mellitus, hepatomegaly, cerebrovascular and cardiovascular diseases among many others [7]. Arsenic generally exerts its toxicity through the generation of reactive oxygen species and the disruption of cellular antioxidant defense system [8].

Another important group of environmental contaminant is the pesticides. The attempts to improve the quality and quantity of crop yields have resulted in a significant rise in the use of pesticides worldwide. Pesticides use has also increased in household activities. The uncontrolled use of these pesticides has led to serious health problems, which is of concern in public health [9]. According to some estimates, millions of people are suffering from severe pesticide poisoning with hundreds of thousands leading to fatalities [10]. Deltamethrin (DM), a type II pyrethroid is a pesticide 
extensively used as an ectoparasiticide on animals and as an insecticide in agriculture and public health programs [11]. Its exposure has been linked to the generation of reactive oxygen species and the resultant oxidative stress in various tissues $[12,13]$.

Individual toxic effects of arsenic and deltamethrin have been well documented, and studies have highlighted the therapeutic potential of several natural agents in protecting against the toxicity induced by either of these toxicants [14-17] There is however, a dearth of information on the protective effect of natural agents against multiple toxic exposure. This study therefore, embarked on an investigation of the efficacy of catechin, a polyphenol against toxicity induced by combined exposure to arsenic and deltamethrin in rats.

\section{Materials and Methods}

\subsection{Chemicals}

Sodium arsenite, catechin, xylenol orange, tripyridyl-5triazine (TPTZ), were procured from Sigma-Aldrich (Munich, Germany). Commercial grade deltamethrin marketed as Deltaforce ${ }^{\circledR}$ (Sobero Organics) was obtained from Irorun Agbe Agrochemical Company (Ogbomoso, Nigeria). ELISA kits for interleukin-6, TNF- $\alpha$, and 8nitroguanine determinations were by Abcam (UK), RayBiotech Inc, (USA), and Cell Biolabs Inc. (USA), respectively. Other chemicals and reagents were all of analytical grade.

\subsection{Animals and Treatment}

Thirty five male Wistar rats weighing 130-150g procured from the Animal House, Faculty of Basic Medical Sciences, Ladoke Akintola University of Technology were used for the study. The animals were kept in plastic cages under controlled laboratory conditions of normal light-dark cycle $\left(12 \mathrm{~h}\right.$ light/dark) and temperature $\left(25 \pm 2^{\circ} \mathrm{C}\right)$. The animals were fed with pelleted diet and water ad libitum. All animal experiments were executed according to the guidelines approved by the Research Ethical Committee of the Faculty of Basic Medical Sciences, Ladoke Akintola university of Technology, Nigeria.

\subsection{Experimental Design}

After a week acclimation period, the rats were weighed and randomly assigned into five groups of seven animals each. Group I (C) served as the control and was given corn oil only at a $1 \mathrm{ml} \mathrm{kg}^{-1}$, while group II (CT) was given CT only at a dose of $40 \mathrm{mg} \mathrm{kg}^{-1}$. Group III (As+DM) was administered with As (100ppm) in their drinking water (Ravuri, 2014) and DM by gavage at a dose of $7.5 \mathrm{mg} \mathrm{kg}^{-1}\left(1 / 20^{\text {th }} \mathrm{LD}_{50}\right)$. Group IV (As+DM-CT 40 ) was treated as group III in addition to oral administration of CT at $40 \mathrm{mg} \mathrm{kg}^{-1}$. Group V (As+DM-CT ${ }_{80}$ ) received the same treatment as group III along with oral CT treatment at a dose of $80 \mathrm{mg} \mathrm{kg}^{-1}$. The different regimens were administered once daily for 28 days. The dose of onetwentieth $\mathrm{LD}_{50}$ for DM was chosen to produce a sub-lethal toxic effect in the animal, while those of CT were based on its therapeutic efficacy, as earlier reported [18]. At the end of the experiment, rats were lightly anaesthetized with ether and blood collected by cardiac puncture. Liver, kidney and testes were excised, weighed, and processed for biochemical assays.

\subsection{Biochemical Analysis}

\subsubsection{Protein Estimation}

The protein content of the organs was determined by the method of Lowry et al [19], using bovine serum albumin as a standard.

\subsubsection{Estimation of Lipid Peroxidation Levels}

Lipid peroxidation in tissues was estimated by the TBA reaction with malondialdehyde, a product of lipid peroxidation process [20]. Tissue homogenate prepared in $0.15 \mathrm{M} \mathrm{KCl}$ was mixed thoroughly with a stock solution containing $15 \% \mathrm{w} / \mathrm{v}$ trichloroacetic acid, $0.375 \% \mathrm{w} / \mathrm{v}$ thiobarbituric acid and $0.25 \mathrm{M} \mathrm{HCl}$. The mixture was heated in a boiling water bath for $15 \mathrm{~min}$ and cooled. The mixture was centrifuged at $1000 \mathrm{~g}$ for $10 \mathrm{~min}$ and the absorbance of the supernatant determined at $535 \mathrm{~nm}$. Using an extinction coefficient of $1.56 \times 10^{5} \mathrm{M}^{-1} \mathrm{~cm}^{-1}$, the concentration of MDA was calculated and expressed as nmol per gram of wet tissue.

\subsubsection{Determination of Lipid Hydroperoxides Concentrations}

Lipid hydroperoxides concentrations in plasma and tissue homogenates were determined using the method of NouroozZadeh et al. [21]. Tissue homogenate was mixed with either $10 \mathrm{mM}$ TPP in methanol or with methanol and incubated for $30 \mathrm{~min}$ at room temperature. FOX2 reagent was added and the mixture incubated for another $30 \mathrm{~min}$. The mixture was centrifuged to remove flocculated material at $12,000 \mathrm{~g}$ for $10 \mathrm{~min}$ after which the absorbance was read at $560 \mathrm{~nm}$.

\subsubsection{Estimation of Protein Oxidation}

Advanced oxidized protein products (AOPP) was measured to assess the level of protein oxidation in the tissue [22]. Homogenate of the sample was prepared with phosphate buffered saline after which $1.16 \mathrm{M}$ potassium iodide and acetic acid were added. The absorbance of the reaction mixture was read at $340 \mathrm{~nm}$ and an extinction coefficient of $261 \mathrm{mM}^{-1} \mathrm{~cm}^{-1}$ was used in calculating AOPP concentrations.

\subsubsection{Determination of Total Antioxidant Capacity (TAC)}

The TAC in samples was estimated using the ferric reducing antioxidant power (FRAP) method described by Benzie and Strain [23]. The FRAP method measures the antioxidant potential through the reduction of ferric tripyridyl-5-triazine ( $\mathrm{Fe}^{3+}$-TPTZ) to its ferrous form $\left(\mathrm{Fe}^{3+}\right)$. Briefly, FRAP working reagent $(300 \mathrm{mM}$ acetate buffer, $\mathrm{pH}$ 3.6, 10mM 2,4,6-tripyridyl-S-triazine in $40 \mathrm{mM} \mathrm{HCl}$ and $20 \mathrm{mM} \mathrm{FeCl}_{3}$ in ratio 10:1:1) was pre-warmed and then mixed with $10 \%$ homogenate of the sample. The procedure was performed at $37^{\circ} \mathrm{C}$, and the absorbance was read at 


\section{$593 \mathrm{~nm}$}

\subsubsection{Determination of Reduced Glutathione (GSH)}

Reduced glutathione content in the organs was determined using the method of Moron et al. [24]. Tissue homogenate was treated with $0.5 \mathrm{ml}$ Ellman's reagent in $0.1 \%$ sodium citrate. After that, phosphate buffer and DTNB were added before the absorbance was read at $412 \mathrm{~nm}$.

\subsubsection{Determination of Catalase (CAT) Activity}

The activity of CAT was measured using the method of Aebi [25]. The assay mixture consisting of supernatant tissue homogenate $(0.1 \mathrm{ml}), 50 \mathrm{mM}$ phosphate buffer $(1.9 \mathrm{ml})$ and $30 \mathrm{mM} \quad \mathrm{H}_{2} \mathrm{O}_{2} \quad(1 \mathrm{ml})$ was maintained at $20^{\circ} \mathrm{C}$. The decomposition of $\mathrm{H}_{2} \mathrm{O}_{2}$ was monitored spectrophotometrically at $240 \mathrm{~nm}$. The change in absorbance was the measure of CAT activity and expressed as nmol/mg protein.

\subsubsection{Determination of Superoxide Dismutase (SOD) Activity}

The method of Misra and Fridovich [26] was used in determining SOD activity in the tissues. The addition of $0.01 \%$ epinephrine $(0.3 \mathrm{ml})$ to the mixture containing $2.5 \mathrm{ml}$ carbonate buffer $(0.05 \mathrm{M})$ and $0.2 \mathrm{ml}$ sample initiated the reaction. Change in absorbance was measured at $480 \mathrm{~nm}$, and the activity was expressed as unit per milligram of protein.

\subsubsection{Determination of Glutathione Peroxidase (GPX) Activity}

GPx activity was determined using $\mathrm{H}_{2} \mathrm{O}_{2}$ as a substrate in the presence of reduced glutathione [27]. The reaction was initiated by adding $0.2 \mathrm{mM} \mathrm{H}_{2} \mathrm{O}_{2}$ to the mixture containing contained $0.2 \mathrm{ml}$ of phosphate buffer $(0.4 \mathrm{M}), 0.1 \mathrm{ml}$ of sodium azide $(10 \mathrm{mM}), 0.2 \mathrm{ml}$ of tissue homogenate and $0.2 \mathrm{ml}$ of GSH. The GSH content was quantified using Ellman's reagent. The activity was expressed as unit per milligram protein where a unit is mmol of GSH consumed per minute.

\subsubsection{Determination of Plasma Interleukin-6 (IL-6), Tumor Necrosis Factor-alpha (TNF- $\alpha$ ) and Nitrative Nucleic Acid Damage}

Plasma concentrations of IL- 6 and TNF- $\alpha$ were determined using commercial rat ELISA kits (Abcam, UK and Ray Biotech Inc, USA, respectively), following the instructions in respective kit manuals. The absorbance was monitored at 450nm on a Hawksley HA-1600 microplate reader (Hawksley, London, U.K.). Plasma concentration of 8-nitroguanine (8$\mathrm{NO}_{2}$-Gua) was evaluated using the nitrosative DNA/RNA damage ELISA kit (Cell Biolabs, Inc. USA), following the procedure provided by the manufacturer.

\subsection{Statistical Analysis}

Data were analyzed by one-way analysis of variance, followed by Tukey's multiple comparisons test. Results were presented as mean \pm standard deviation (SD) and values were considered statistically significant at $p<0.05$. Data were analyzed using GraphPad Prism for Windows, version 6.01 (GraphPad Software, Inc., San Diego, CA, USA.).

\section{Results}

\subsection{Effect on Lipid Peroxidation and Protein Oxidation Indices}

Table 1 shows the combined effects of arsenic and deltamethrin, along with catechin treatment on MDA, LOOH and AOPP levels in liver, kidney and testis tissues. Administration of CT to normal rats exerted no significant difference on the lipid peroxidation and protein oxidation markers. Tissue MDA, $\mathrm{LOOH}$, and AOPP contents were however, increased significantly on exposure to $A s$ in combination with DM. CT treatments caused significantly reduction of these parameters in the co-exposed animals. The polyphenol particularly restored hepatic MDA and AOPP levels to normal, while drastically lowering all the markers of oxidative injury in all other organs.

Table 1. Effects of catechin treatment on MDA, LOOH and AOPP levels in liver, kidney, and testis of rats co-exposed to arsenic and deltamethrin.

\begin{tabular}{lllll}
\hline \multirow{2}{*}{ Groups } & Liver & & Kidney \\
\cline { 2 - 5 } & MDA $(\mathbf{n m o l} / \mathbf{g}$ tissue) & LOOH $(\mathbf{n m o l} / \mathbf{g}$ tissue) & AOPP $(\boldsymbol{\mu m o l} / \mathbf{g}$ tissue) & MDA (nmol/g tissue) \\
\hline Control & $31.29 \pm 3.07^{\mathrm{a}}$ & $7.14 \pm 0.63^{\mathrm{a}}$ & $39.27 \pm 1.95^{\mathrm{a}}$ & $18.58 \pm 1.24^{\mathrm{a}}$ \\
CT & $30.86 \pm 2.72^{\mathrm{a}}$ & $7.21 \pm 0.43^{\mathrm{a}}$ & $37.16 \pm 1.72^{\mathrm{a}}$ & $18.10 \pm 1.11^{\mathrm{a}}$ \\
As $+\mathrm{DM}$ & $53.65 \pm 3.81^{\mathrm{b}}$ & $21.05 \pm 1.54^{\mathrm{b}}$ & $48.07 \pm 2.34^{\mathrm{b}}$ & $34.25 \pm 2.34^{\mathrm{b}}$ \\
As $^{\mathrm{D} M}-\mathrm{CT}_{40}$ & $35.12 \pm 2.35^{\mathrm{a}}$ & $11.36 \pm 1.89^{\mathrm{c}}$ & $36.94 \pm 2.13^{\mathrm{a}}$ & $26.76 \pm 1.92^{\mathrm{a}}$ \\
As $^{\mathrm{a}} \mathrm{DM}-\mathrm{CT}_{80}$ & $32.33 \pm 2.84^{\mathrm{a}}$ & $9.05 \pm 0.61^{\mathrm{d}}$ & $36.10 \pm 2.73^{\mathrm{a}}$ & $23.55 \pm 1.81^{\mathrm{d}}$ \\
\hline
\end{tabular}

Table 1. Continued.

\begin{tabular}{|c|c|c|c|c|c|}
\hline \multirow{2}{*}{ Groups } & \multicolumn{2}{|l|}{ Kidney } & \multicolumn{3}{|l|}{ Testis } \\
\hline & LOOH (nmol/g tissue) & AOPP $(\mu \mathrm{mol} / \mathrm{g}$ tissue $)$ & MDA (nmol/g tissue) & LOOH (nmol/g tissue) & AOPP $(\mu \mathrm{mol} / \mathrm{g}$ tissue $)$ \\
\hline Control & $5.01 \pm 0.34^{\mathrm{a}}$ & $12.61 \pm 0.32^{\mathrm{a}}$ & $11.55 \pm 1.33^{\mathrm{a}}$ & $1.85 \pm 0.18^{\mathrm{a}}$ & $40.67 \pm 1.69^{\mathrm{a}}$ \\
\hline CT & $4.76 \pm 0.31^{\mathrm{a}}$ & $12.79 \pm 0.28^{\mathrm{a}}$ & $10.12 \pm 0.84^{\mathrm{a}}$ & $1.56 \pm 0.21^{\mathrm{a}}$ & $38.31 \pm 2.05^{\mathrm{a}}$ \\
\hline $\mathrm{As}+\mathrm{DM}$ & $12.52 \pm 1.57^{b}$ & $41.61 \pm 4.65^{\mathrm{b}}$ & $28.24 \pm 2.37^{\mathrm{b}}$ & $4.89 \pm 0.52^{b}$ & $77.50 \pm 5.12^{\mathrm{b}}$ \\
\hline $\mathrm{As}+\mathrm{DM}-\mathrm{CT}_{40}$ & $7.74 \pm 0.85^{\mathrm{c}}$ & $13.66 \pm 1.33^{\mathrm{ac}}$ & $15.56 \pm 1.84^{\mathrm{c}}$ & $2.62 \pm 0.25^{\mathrm{c}}$ & $37.50 \pm 2.00^{\mathrm{a}}$ \\
\hline $\mathrm{As}+\mathrm{DM}-\mathrm{CT}_{80}$ & $7.18 \pm 0.49^{c}$ & $16.60 \pm 1.28^{\mathrm{c}}$ & $13.56 \pm 1.55^{\mathrm{ac}}$ & $2.17 \pm 0.24^{\mathrm{ac}}$ & $37.57 \pm 1.33^{\mathrm{a}}$ \\
\hline
\end{tabular}

MDA: malondialdehyde; LOOH: lipid hydroperoxide; AOPP: advanced oxidized protein product.

Data are expressed as means \pm S. D. of seven animals per group. Values in the same column, not sharing the same superscript are significantly different from each other at $\mathrm{p}<0.05$. 


\subsection{Effects on Antioxidant Systems}

Table 2 depicts the enzymatic and non-enzymatic antioxidant status in control rats and groups exposed to combined As and DM alone or co-administered with CT. There were no significant changes in activities of SOD, CAT, and GPx in rats treated with CT alone. Combined As and DM treatment caused significant $(p<0.05)$ reduction in the activities of SOD and GPx in the liver $(65 \%$ and $40 \%$, respectively), kidney ( $70 \%$ and $40 \%$, respectively), and testis (63\% and 36\%, respectively) when compared with the control. However, co-treatment with CT reversed this trend in all the organs, with CT administration fully restoring hepatic SOD activity and GPx activities in both the liver and kidney. Combined As and DM also reduced hepatic and renal CAT activities but the enzyme activity was increased in the testis. CT administration at high dose restored the enzyme activities in both the kidney and testis in the exposed rats. Hepatic CAT activity was significantly increased by both $\mathrm{CT}$ doses, when compared with the animals treated with combined As and DM alone. The levels of GSH and TAC were significantly ( $p<$ 0.05) decreased in the liver, kidney and testis of As and DM treated rats when compared with the control. No significant change was observed in the hepatic content of GSH of animals co-exposed to As and DM but treated with either doses of CT. The kidney and testis GSH levels, along with TAC in all the tissues of rats exposed to the chemical mixture but treated with CT were significantly increased above that of the animals treated with combined As and DM alone.

Table 2. Effects of epicatechin treatment on enzymatic and non-enzymatic antioxidant status in liver and kidney of Cypermethrin intoxicated rats after 14 days.

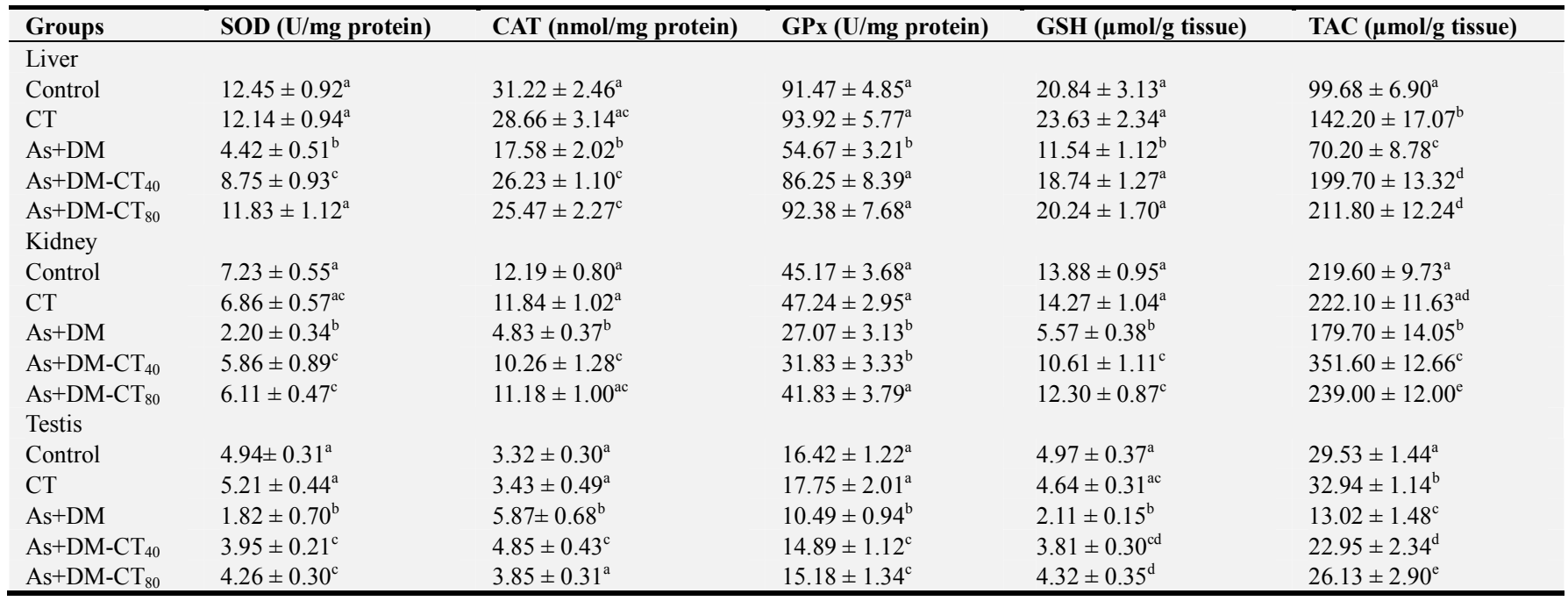

SOD: superoxide dismutase; CAT: catalase; GPx: glutathione peroxidase; GSH: reduced glutathione; TAC: total antioxidant capacity. Data are expressed as means \pm S. D. of seven animals per group. Values in the same column for a compartment, not sharing the same superscript are significantly different from each other at $\mathrm{p}<0.05$.

\subsection{Effect on Pro-inflammatory Cytokines}

B
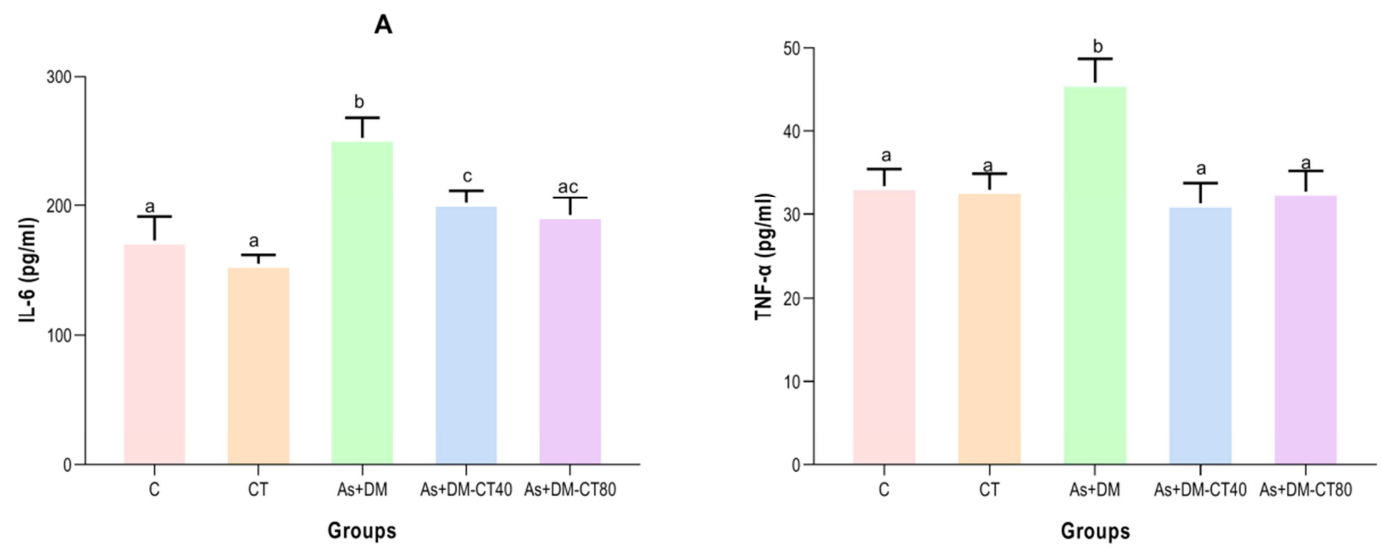

Figure 1. Effect of catechin treatment on plasma IL-6 (A) and TNF-a (B) levels in rats co-exposed to As and DM.

The concentrations of IL-6 and TNF- $\alpha$ in the plasma of combined As and DM-exposed and CT-administered rats are shown in Figure 1. Administration of CT alone has no significant effect on the levels of inflammatory markers. 
However, the pro-inflammatory cytokines levels were increased significantly $(\mathrm{p}<0.05)$ in the co-exposed rats. The concentrations of IL- 6 and TNF- $\alpha$ in the plasma were increased by $46 \%$ and $37 \%$ respectively above the control.
CT co-treatment significantly reduced the elevated proinflammatory cytokines induced by the combination of As and DM, with the high CT dose treatment restoring the levels to normal.

\subsection{Assessment of Nitrosative Damage to Nucleic Acids}

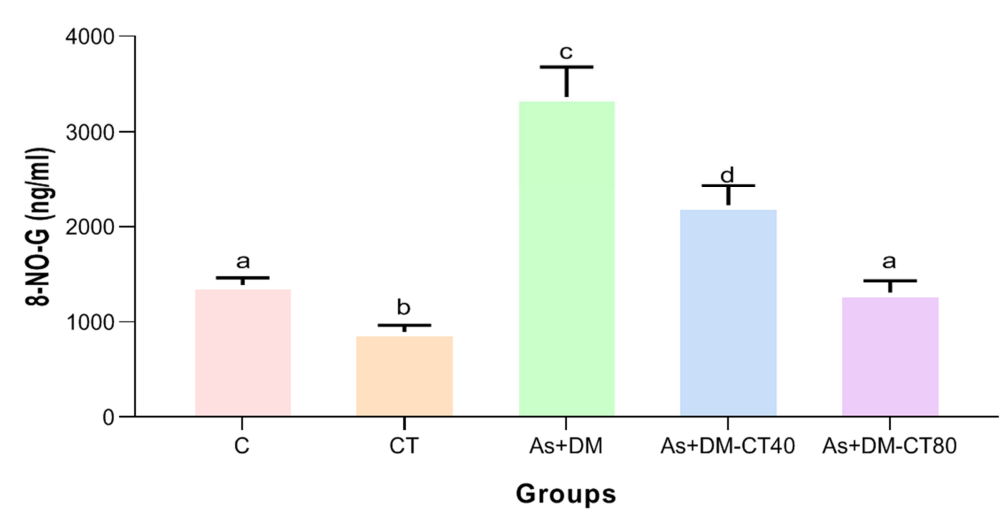

Figure 2. Effect of catechin treatment on plasma 8-NO2-Gua levels in rats co-exposed to As and DM.

Figure 2 depicts the levels of nitrosative damage in the rats. Co-exposure to As and DM is characterized by a significant increase in plasma concentration of $8-\mathrm{NO}_{2}$-Gua in the rats $(\mathrm{p}<0.05)$. Combined As and DM intoxication resulted in a $142 \%$ increase in the level of $8-\mathrm{NO}_{2}$-Gua when compared with the control. Co-treatment of As and DMexposed rats with CT significantly reduced the formation of nitrosative nucleic acids. The nitrosative nucleic acid content in the rats treated with high dose CT was not significantly different from the control. Interestingly, CT alone reduced $8-\mathrm{NO}_{2}$-Gua level in normal rat by $36 \%$.

\section{Discussion}

Environmental pollutants such as pesticides and heavy metals are known to cause serious health effects through the induction of wide range of toxicological events and biochemical dysfunctions. Some earlier studies on combined exposure to pesticides and heavy metals have reported among others, immunotoxic, hematologic, and calcium homeostasis disruptive effects of these environmental contaminants [28, 29]. There is however, a paucity of information on the use of natural agents in preventing or ameliorating these toxic effects. The present study therefore, describes the effectiveness of oral CT administration in preventing oxidative stress and inflammation induced by combined As and DM exposure in the rat. Oxidative imbalance induced by arsenic and DM has been well reported, resulting from increased free radical generation and depletion of antioxidant defense system induced by these toxicants $[12,30]$. In the present study, results show that the combination of the toxicants caused an imbalance in the oxidative status and increased inflammation in the exposed rats which CT was able to attenuate.

Even though liver and kidney play roles in detoxification, their chronic exposure to xenobiotics and their derivatives make them susceptible to oxidative damage [31]. On the other hand, the high polyunsaturated fatty acid content along with the low antioxidant capacity make testicular tissues prone to attack from ROS [32]. In this study, co-exposure to As and DM resulted in the inhibition of all the antioxidant enzyme activities measured except in the testis, where the toxicants caused an increase in CAT activity. Inhibition of antioxidant enzyme activity has been reported following exposure of animals to either As or DM [33-36]. The observed decrease in SOD, CAT and GPx activities may be due to oxidative inactivation of the proteins arising through the damaging effect of free radicals generated by both As and DM. The damage may result from the accumulation of the insecticide in the tissue, together with the disruption of the protein's thiol groups by arsenic [31]. Inhibition of these enzymes is often accompanied by a depletion of GSH as evidenced in this study, and/or increased hydrogen peroxide generation, giving rise to oxidative stress [37]. The increase observed in testicular CAT activity may be an adaptive response by the tissue to counter the increased generation of ROS through increased expression of the protein. Pretreatment with CT however, ameliorated the disruption caused by the co-exposure to As and DM to the antioxidant enzyme activities, with a total restoration of activity generally observed with the high dose of the polyphenol.

GSH and GPx are detoxifying agents that convert $\mathrm{H}_{2} \mathrm{O}_{2}$ and lipid peroxides to nontoxic products. The depleted GSH concentration caused by increased oxidative stress burden could induce lipid and protein oxidation [38]. In our study, this is reflected by the marked increase in tissue MDA, LOOH, and AOPP contents in the co-exposed rats. Several authors have also demonstrated increased oxidative stress following co-exposure to multiple chemical mixtures [11, 39, 40]. Either As or DM alone, can enhance lipid peroxidation through interaction with cellular membranes [41, 42]. Increased generation of lipid peroxides can result in the depletion of lipid soluble antioxidant system like GSH, leading to the inhibition of GSH-dependent antioxidant enzymes, such as GPx. The resultant effect of this would be 
an increased susceptibility of the enzymatic antioxidant system to oxidative damage, contributing to their reduced activity. The increase in ROS production could also contribute to the generation of oxidized proteins observed in all the tissues investigated, the resulting modification might have added to the decrease in enzyme activities found in this study. CT treatment significantly attenuated the lipid peroxidation and reversed the oxidant-mediated protein damaging effects of the toxicants. Co-exposure to As and DM was characterized by reduced hepatic, renal and testicular antioxidant potential as indicated by the lowered FRAP level in the rats. The relative cumulative capacity of the total antioxidant system was reflected by the antioxidant capacity estimation. The reduction in TAC by AS and DM co-administration is an indication of the depletion of the antioxidant system capacity in the organs. Results from this study, however, suggested that concomitant treatment with CT normalized the TAC level in all the organs.

The toxic effects elicited by co-exposure to As and DM were all significantly reduced or completely reversed by treatment with $\mathrm{CT}$. Although reports are not readily available about the protective effect of CT against combined As and DM induced toxicity, there are earlier reports of its ability to protect against chemically induced oxidative stress and inflammation $[43,44]$. In the present study, CT restored the activities of the antioxidant enzymes SOD, CAT and GPx, while suppressing the generation of $\mathrm{MDA}, \mathrm{LOOH}$, and AOPP in the organs. The improvement of the oxidative mediated impairment of the tissues in As and DM coexposed rats by $\mathrm{CT}$ indicated that the polyphenol effectively scavenged free radicals and attenuated the oxidative damage. Previous studies have shown CT to be an effective agent able to scavenge and remove deleterious toxic radicals that could disrupt antioxidant enzyme activities and cause tissue injury $[43,45]$. Studies have also demonstrated that catechin could inhibit excessive oxidative stress through direct or indirect antioxidant effects and can reduce oxidative damage to tissues through the promotion of antioxidant substances such as GPx and GSH [44]. The antioxidant properties of CT may thus be employed to improve the redox status in the tissues following exposure to multiple toxicants, such as As and DM.

The present investigation also revealed that coadministration of As and DM triggered significant increase in the level of pro-inflammatory cytokines, IL- 6 and TNF- $\alpha$, as well as, the nitrative nucleic acid marker, 8- $\mathrm{NO}_{2}$-Gua. Increased oxidative stress can induce inflammation through the activation of redox-sensitive factors [46]. The elevated IL-6 and TNF- $\alpha$ levels observed could thus, be a result of these redox-sensitive factors, activated by combined As and DM induced oxidative stress. Several studies have shown that either toxicant can induce the expression of proinflammatory cytokines $[7,47] .8-\mathrm{NO}_{2}$-Gua is a product of the interaction of the highly reactive peroxynitrite, formed when nitric oxide synthase reacts with superoxide, and guanine, during inflammation [48]. Elevated plasma $8-\mathrm{NO}_{2}-$ Gua level in the rats further corroborates the inducement of inflammation by co-administration of As and DM. The effect of CT on $8-\mathrm{NO}_{2}$-Gua level in these rats reflected the antiinflammatory property of $\mathrm{CT}$ against the inflammatory response induced by co-exposure to As and DM. Plasma TNF- $\alpha$, IL-6 and 8-NO ${ }_{2}$-Gua levels were normalized by CT administration. Catechins are reported to exert their antiinflammatory properties by regulating the activation of inflammation-related oxidative stress-related cell signaling pathway, such as nuclear factor-kappa $\mathrm{B}(\mathrm{NF}-\kappa \mathrm{B})$, mitogen activated protein kinases (MAPKs), transcription factor nuclear factor (erythroid-derived 2)-like 2 (Nrf2), signal transducer and the activator of transcription 1/3 (STAT1/3) pathways. Catechin also exerts its anti-inflammatory function by decreasing the expression of inflammatory cytokines [43].

\section{Conclusion}

In conclusion, the present study indicate that combined exposure to As and DM resulted in marked imbalance in oxidative status and aggravated inflammatory response in the tissues of rats. These alterations were, however, mitigated by treatment with CT. The study, therefore, showed that supplementation with $\mathrm{CT}$ has beneficial effect on toxicities evoked by co-exposure to As and DT, and potentially, on injuries caused by exposure to other multiple toxicants.

\section{Statement of Competing Interests}

The authors have no competing interests.

\section{References}

[1] Tchounwou PB, Yedjou CG, Patlolla AK, Sutton DJ. Heavy metal toxicity and the environment. Molecular, clinical and environmental toxicology: Springer; 2012. p. 133-64.

[2] Zikankuba VL, Mwanyika G, Ntwenya JE, James A. Pesticide regulations and their malpractice implications on food and environment safety. Cogent Food \& Agriculture 2019; 5: 1601544.

[3] ATSDR U. Toxicological Profile for Arsenic. Agency for Toxic Substances and Disease Registry. US Department of Health and Human Services, Centers for Disease Control and Prevention; 2007.

[4] Flora S, Dwivedi N, Deb U, Kushwaha P, Lomash V. Effects of co-exposure to arsenic and dichlorvos on glutathione metabolism, neurological, hepatic variables and tissue histopathology in rats. Toxicology Research 2014; 3: 23-31.

[5] Hughes MF, Beck BD, Chen Y, Lewis AS, Thomas DJ. Arsenic exposure and toxicology: a historical perspective. Toxicological Sciences 2011; 123: 305-32.

[6] Mazumder DG, Dasgupta U. Chronic arsenic toxicity: studies in West Bengal, India. The Kaohsiung journal of medical sciences 2011; 27: 360-70.

[7] Peters BA, Liu X, Hall MN, Ilievski V, Slavkovich V, Siddique AB, et al. Arsenic exposure, inflammation, and renal function in Bangladeshi adults: effect modification by plasma glutathione redox potential. Free Radical Biology and Medicine 2015; 85: 174-82. 
[8] Jomova K, Jenisova Z, Feszterova M, Baros S, Liska J, Hudecova $\mathrm{D}$, et al. Arsenic: toxicity, oxidative stress and human disease. Journal of Applied Toxicology 2011; 31: 95107.

[9] Debnath M, Khan MS. Health concerns of pesticides. Pesticide Residue in Foods: Springer; 2017. p. 103-18.

[10] Wani WY, Gudup S, Sunkaria A, Bal A, Singh PP, Kandimalla RJ, et al. Protective efficacy of mitochondrial targeted antioxidant MitoQ against dichlorvos induced oxidative stress and cell death in rat brain. Neuropharmacology 2011; 61: 1193-201.

[11] Khan AM, Raina R, Dubey N, Verma PK. Effect of deltamethrin and fluoride co-exposure on the brain antioxidant status and cholinesterase activity in Wistar rats. Drug and chemical toxicology 2018; 41: 123-7.

[12] Dubey N, Khan AM, Raina R. Sub-acute deltamethrin and fluoride toxicity induced hepatic oxidative stress and biochemical alterations in rats. Bulletin of environmental contamination and toxicology 2013; 91: 334-8.

[13] Dubey N, Raina R, Khan AM. Toxic effects of deltamethrin and fluoride on antioxidant parameters in rats. Fluoride 2012; 45: 242-6.

[14] Ncir M, Saoudi M, Sellami H, Rahmouni F, Lahyani A, Makni Ayadi F, et al. In vitro and in vivo studies of Allium sativum extract against deltamethrin-induced oxidative stress in rats brain and kidney. Archives of physiology and biochemistry 2018; 124: 207-17.

[15] Ogaly HA, Khalaf A, Ibrahim MA, Galal MK, Abd-Elsalam RM. Influence of green tea extract on oxidative damage and apoptosis induced by deltamethrin in rat brain. Neurotoxicology and teratology 2015; 50: 23-31.

[16] Pace C, Dagda R, Angermann J. Antioxidants protect against arsenic induced mitochondrial cardio-toxicity. Toxics 2017; 5: 38 .

[17] Sárközi K, Papp A, Máté Z, Horváth E, Paulik E, Szabó A. Rutin, a flavonoid phytochemical, ameliorates certain behavioral and electrophysiological alterations and general toxicity of oral arsenic in rats. Acta biologica hungarica 2015; 66: $14-26$

[18] Samarghandian S, Azimi-Nezhad M, Farkhondeh T. Catechin treatment ameliorates diabetes and its complications in streptozotocin-induced diabetic rats. Dose-Response 2017; 15: 1559325817691158 .

[19] Lowry OH, Rosebrough NJ, Farr AL, Randall RJ. Protein measurement with the Folin phenol reagent. Journal of biological chemistry 1951; 193: 265-75.

[20] Buege JA, Aust SD. Microsomal lipid peroxidation. Methods in enzymology: Elsevier; 1978. p. 302-10.

[21] Nouroozzadeh J, Tajaddinisarmadi J, Wolff SP. Measurement of plasma hydroperoxide concentrations by the ferrous oxidation-xylenol orange assay in conjunction with triphenylphosphine. Analytical biochemistry 1994; 220: 403-9.

[22] Witko-Sarsat V, Friedlander $M$, Capeillère-Blandin C, Nguyen-Khoa T, Nguyen AT, Zingraff J, et al. Advanced oxidation protein products as a novel marker of oxidative stress in uremia. Kidney international 1996; 49: 1304-13.
[23] Benzie IF, Strain JJ. The ferric reducing ability of plasma (FRAP) as a measure of "antioxidant power": the FRAP assay. Analytical biochemistry 1996; 239: 70-6.

[24] Moron MS, Depierre JW, Mannervik B. Levels of glutathione, glutathione reductase and glutathione S-transferase activities in rat lung and liver. Biochimica et Biophysica Acta (BBA)General Subjects 1979; 582: 67-78.

[25] Aebi H. Catalase. Methods of enzymatic analysis: Elsevier; 1974. p. 673-84.

[26] Misra HP, Fridovich I. The role of superoxide anion in the autoxidation of epinephrine and a simple assay for superoxide dismutase. Journal of Biological chemistry 1972; 247: 3170-5.

[27] Rotruck JT, Pope AL, Ganther HE, Swanson A, Hafeman DG, Hoekstra W. Selenium: biochemical role as a component of glutathione peroxidase. Science 1973; 179: 588-90.

[28] Singh N, Gupta VK, Kumar A, Sharma B. Synergistic effects of heavy metals and pesticides in living systems. Frontiers in chemistry $2017 ; 5: 70$.

[29] Adamkovicova M, Toman R, Cabaj M, Massanyi P, Martiniakova M, Omelka R, et al. Effects of subchronic exposure to cadmium and diazinon on testis and epididymis in rats. The Scientific World Journal 2014; 2014.

[30] Pachauri V, Mehta A, Mishra D, Flora SJ. Arsenic induced neuronal apoptosis in guinea pigs is $\mathrm{Ca}_{2+}$ dependent and abrogated by chelation therapy: role of voltage gated calcium channels. Neurotoxicology 2013; 35: 137-45.

[31] Uchendu C, Ambali SF, Ayo JO, Esievo KA. The protective role of alpha-lipoic acid on long-term exposure of rats to the combination of chlorpyrifos and deltamethrin pesticides. Toxicology and industrial health 2017; 33: 159-70.

[32] Afolabi OK, Wusu AD, Ugbaja R, Fatoki JO. Aluminium phosphide-induced testicular toxicity through oxidative stress in Wistar rats: Ameliorative role of hesperidin. Toxicology Research and Application 2018; 2: 2397847318812794.

[33] Oliveira JM, Losano NF, Condessa SS, de Freitas RMP, Cardoso SA, Freitas MB, et al. Exposure to deltamethrin induces oxidative stress and decreases of energy reserve in tissues of the Neotropical fruit-eating bat Artibeus lituratus. Ecotoxicology and environmental safety 2018; 148: 684-92.

[34] Saoudi M, Badraoui R, Bouhajja H, Ncir M, Rahmouni F, Grati M, et al. Deltamethrin induced oxidative stress in kidney and brain of rats: Protective effect of Artemisia campestris essential oil. Biomedicine \& Pharmacotherapy 2017; 94: 95563.

[35] Altikat S, Uysal K, Kuru HI, Kavasoglu M, Ozturk GN, Kucuk A. The effect of arsenic on some antioxidant enzyme activities and lipid peroxidation in various tissues of mirror carp (Cyprinus carpio carpio). Environmental Science and Pollution Research 2015; 22: 3212-8.

[36] Bashandy SA, El Awdan SA, Ebaid H, Alhazza IM. Antioxidant potential of Spirulina platensis mitigates oxidative stress and reprotoxicity induced by sodium arsenite in male rats. Oxidative medicine and cellular longevity 2016; 2016.

[37] Demir F, Uzun FG, Durak D, Kalender Y. Subacute chlorpyrifos-induced oxidative stress in rat erythrocytes and the protective effects of catechin and quercetin. Pesticide Biochemistry and Physiology 2011; 99: 77-81. 
[38] El-Desoky GE, Bashandy SA, Alhazza IM, Al-Othman ZA, Aboul-Soud MA, Yusuf K. Improvement of mercuric chloride-induced testis injuries and sperm quality deteriorations by Spirulina platensis in rats. PLoS One 2013; 8: e59177.

[39] Dwivedi N, Flora G, Kushwaha P, Flora SJ. Alpha-lipoic acid protects oxidative stress, changes in cholinergic system and tissue histopathology during co-exposure to arsenic-dichlorvos in rats. Environmental toxicology and pharmacology 2014; 37: $7-23$.

[40] Dwivedi N, Flora SJ. Concomitant exposure to arsenic and organophosphates on tissue oxidative stress in rats. Food and chemical toxicology 2011; 49: 1152-9.

[41] Yousefi B, Ahmadi Y, Ghorbanihaghjo A, Faghfoori Z. Serum arsenic and lipid peroxidation levels in patients with multiple sclerosis. Biological trace element research 2014; 158: 276-9.

[42] Sharma DK, Ansari BA. Effects of deltamethrin on CAT, LPO and GSH in tissues of zebra fish Danio rerio. Research Journal of Environmental Toxicology 2013; 7: 38-46.

[43] El-Aziz TAA, Mohamed RH, Pasha HF, Abdel-Aziz HR. Catechin protects against oxidative stress and inflammatorymediated cardiotoxicity in adriamycin-treated rats. Clinical and experimental medicine $2012 ; 12: 233-40$.
[44] Fan F-Y, Sang L-X, Jiang M. Catechins and their therapeutic benefits to inflammatory bowel disease. Molecules 2017; 22: 484.

[45] Mehra P, Garg M, Koul A, Bansal DD. Effect of (+)-catechin hydrate on oxidative stress induced by high sucrose and high fat diet in male Wistar rats. 2013.

[46] Forrester SJ, Kikuchi DS, Hernandes MS, Xu Q, Griendling KK. Reactive oxygen species in metabolic and inflammatory signaling. Circulation Research 2018; 122: 877-902.

[47] Arslan H, Altun S, Özdemir S. Acute toxication of deltamethrin results in activation of iNOS, 8-OHdG and up-regulation of caspase 3, iNOS gene expression in common carp (Cyprinus carpio L.). Aquatic Toxicology 2017; 187: 90-9.

[48] Hiraku Y, Sakai K, Shibata E, Kamijima M, Hisanaga N, Ma $\mathrm{N}$, et al. Formation of the Nitrative DNA Lesion 8nitroguanine is Associated with Asbestos Contents in Human Lung Tissues: A Pilot Atudy. Journal of occupational health 2014: 13-0231-OA. 